\title{
E-learning course for Norwegian caregivers
}

\author{
Gro Trae \\ From 7th European Conference on Rare Diseases and Orphan Products (ECRD 2014)
}

\section{Objectives}

Frambu Resource Centre for Rare Disorders in Norway has registered 140 persons with Prader-Willi Syndrome (PWS), and often receives inquiries on telephone and e-mail about different aspects concerning this group. Frambu offer local guidance and courses at Frambu, but with limited time resources for local guidance, as well as limited possibilities for local caregivers to participate in courses at Frambu, we found it necessary to distend our competence services for this group.

The aim was to provide essential education about PWS to caregivers that work in group homes all over Norway to ensure better and closer follow-up for people with PWS. Our goal was to develop an electronic course to caregivers, as a new competence service from Frambu that will supplement our traditional services.

\section{Methods}

A group of five professionals from Frambu was in the project group. Through workshops and meetings we have developed learning goals for eight different themes, concerning different aspects of daily life of a person with PWS. The Norwegian Prader-Willi association, caregivers and other professionals with competence on PWS have participated in this work.

\section{Results}

The e-learning course was accessible in Norwegian on the internet in December 2012. The content of the e-learning course appears through videos and photos of people with PWS, interactive tasks, case examples and written information.

\section{Conclusions}

Frambu Resource Centre for Rare Disorders has developed a new education tool for caregivers. By August 2014255 caregivers have finished the course, and the response and feedback is very positive. The evaluation shows that the participants found the content of the

Frambu Resource Centre for Rare Disorders, Oslo, Norway course useful, that they became motivated to change their practise at work, and that the course was a good alternative to physical course gatherings. In conclusion we can say that e-learning is an effective tool for teaching caregivers about rare disorders.

Published: 11 November 2014

doi:10.1186/1750-1172-9-S1-P12

Cite this article as: Trae: E-learning course for Norwegian caregivers.

Orphanet Journal of Rare Diseases 2014 9(Suppl 1):P12.

\author{
Submit your next manuscript to BioMed Central \\ and take full advantage of: \\ - Convenient online submission \\ - Thorough peer review \\ - No space constraints or color figure charges \\ - Immediate publication on acceptance \\ - Inclusion in PubMed, CAS, Scopus and Google Scholar \\ - Research which is freely available for redistribution

() Biomed Central

(c) 2014 Trae; licensee BioMed Central Ltd. This is an Open Access article distributed under the terms of the Creative Commons Attribution License (http://creativecommons.org/licenses/by/4.0), which permits unrestricted use, distribution, and reproduction in any medium, provided the original work is properly cited. The Creative Commons Public Domain Dedication waiver (http://creativecommons.org/publicdomain/zero/1.0/) applies to the data made available in this article, unless otherwise stated. 